Journal of Social Sciences (COES\&RJ-JSS)

ISSN (E): 2305-9249 ISSN (P): 2305-9494

Publisher: Centre of Excellence for Scientific \& Research Journalism, COES\&RJ LLC

Online Publication Date: $1^{\text {st }}$ October 2016

Online Issue: Volume 5, Number 4, October 2016

http://centreofexcellence.net/J/JSS/JSS\%20Mainpage.htm

\title{
Relationship individual characteristics, group characteristics, organizations structure, organizational culture and organizational climate with organizational effectiveness colleges in Malang
}

\author{
Arie Ambarwati ${ }^{1}$, Sonhadji ${ }^{2}$, I Nyoman S Degeng ${ }^{3}$, Bambang Budi Wiyono ${ }^{4}$ \\ ${ }^{1}$ Lecturer, STIE Indonesia Malang, East Java, Indonesia \\ ${ }^{2,3,4}$ Professor of Education Administration, State University of Malang, East Java, \\ Indonesia
}

\begin{abstract}
:
This research was an ex post facto research which did not provide any control or manipulation of variables directly by the researchers. Embodiments of the independent variables have occurred naturally or cannot be manipulated, researchers tried to explain the facts that have occurred. The research design used in this research was descriptivecorrelational design to obtain information regarding the observed phenomena and to describe the presence or absence of a relationship between the characteristics of individuals and groups, structure, culture and organizational climate of the effectiveness of the organization internally by large-small correlation coefficient. This was a quantitative approach usinf Structural Equation Modeling (SEM) based variants method. The independent variables (exogenous) were individual characteristics (X1), and the characteristics of the group (X2), organizational structure (X3), organizational culture (X4) and organizational climate (X5). The effectiveness of the organization was the dependent variable or endogenous variables in this study. The results of modeling the relationship among six variables studied were generated in this study including: (1) the individual characteristics of the lecturers which were not directly related to the effectiveness of the college, (2) characteristics of the group has a direct relationship with effectiveness, and organizational structure, as well as having no relationship directly to the effectiveness of organizations through the organizational structure, (3) organizational structure directly affected the effectiveness of the organization, but did not have any direct contact with the culture and climate of the organization, (4) a direct relationship was significant relationship between culture and organizational climate to organizational effectiveness, as well as the subsequent results the findings in this study were (5) the existence of a significant direct relationship between organizational climate with the culture of the organization.
\end{abstract}

\section{Keywords:}

individual characteristics, group characteristics, organizational structure, organizational culture, organizational climate, organizational effectiveness

\section{Citation:}

Ambarwati, Arie; Sonhadji; Degeng, I Nyoman S; Wiyono, Bambang Budi (2016); Relationship individual characteristics, group characteristics, organizations structure, organizational culture and organizational climate with organizational effectiveness colleges in Malang; Journal of Social Sciences (COES\&RJ-JSS), Vol.5, No.4, pp: 506522 .

This work is licensed under a Creative Commons Attribution 4.0 International License. 


\section{INTRODUCTION}

Private Higher Education (PTS) as a partner State Universities (PTN) has an equal footing, after the issuance of PP 30 of 1990 on Higher Education. The alignment is shown with the enactment of the regulation without distinguishing state and private universities. The element that most distinguishes it is the PTS Organizing Body (BP-PTS) in the form of foundations, social associations, or bodies waq (BM-PTSI Kopertis Region VII, 19971998). PTS itself for a more independent institution in the provision of funds, facilities, personnel training, and admissions compared with PTN. The existence of the Foundation in PTS played a role in achieving efficiency and effectiveness of the management of private universities. private universities (PTS) has certain characteristics that differentiate among one another or with public universities (PTN). Based on the observations of researchers to PTS, there are situations that distinguish between PTN with PTS, among others in PTS there is unity of the mission, the employee with salary limitations still have high morale, family ties are very strong, and some private universities are not too cling to the bureaucratic aspects of the organization, as well as attention to the aspects of leadership that a high figure (these observations still need to be tested for truth).

The number and capacity of public universities are limited is one of the factors which a private college established. Another thing that underlies the establishment of a private university is as a form of public participation in the field of higher education as mandated in Law No. 20 of 2003 on the education system in Indonesia. Private colleges as part of the higher education system indirectly coloring a wide range of higher education policy in Indonesia.

Review the organization is basically aimed to understand and study the effectiveness of an organization. Studies on the effectiveness of the organization has been much in demand by experts from various disciplines. Experts sociology, social psychology, and economics has reviewed the effectiveness of the organization from the perspective view (Miller, 1979). The viewpoint was different studies. There are reviewing the terms of the system, the bureaucracy, and cognition (Gordon et al, 1990), there were reviewing the terms of the achievement of objectives, the availability of resources, internal processes, and member satisfaction (Kreitner and Kinicki, 1992).

Organizational dynamics that exist in the private colleges will affect the effectiveness and success in achieving organizational goals, it is when the private universities is seen as an organization with all the elements that form and build sustainability of the organization. Robbin (2003), in studying an organization there are several steps that must be learned, namely: (1) the individual level, (2) Level group / groups, (3) Level the organizational system. Organizational dynamics can also be viewed from a number of approaches. Daft da Steers (1986) looked at the organization of the two approaches, namely micro approach in this regard include: (1) analysis at the individual level, and (2) analysis at the level of the group / groups, as well as the approach to macro that includes the analysis at the organizational level.

Lecturer as a major pillar in higher education very important role in developing Tridarma universities and the creation of academic feel that konduksif for the implementation Tridarma Perguruan Tinggi. The existence of the law on teachers and lecturers to enable teachers earn the most attention from the government as the spearhead of improving the quality of human resources in Indonesia in the future. The existence of foreign professors 
seconded to private colleges also provide its own color to the formation of organizational culture and climate at private colleges. The emergence of a group of lecturers country seconded to the private universities and a group of tenured faculty foundation also creates its own dynamics in the private colleges, from which not infrequently raised social jealousy amongst the group of lecturers of the facilities, and the rewards that may be felt not give a fair sense between the two groups. The gap between domestic lecturer seconded to the private college with a permanent lecturer foundations can lead to conflict which can reduce the effectiveness of the private universities. Many of the factors causing the gap between the two groups. Factors that often arises among others, with respect to the certification of teachers, lecturers discipline, as well as the perceived performance of lecturers in favor of certain parties. The emergence of conflicts in the organization will affect the climate and culture of the organization that will lead to more controversy and divisions within the organization. Conflict within an organization can be minimized if the figure founder and head of the organization to accommodate and facilitate and be a mediator in addressing and resolving conflicts and disputes groups within the organization.

This research is expected to contribute in the development of science and technologySosbud through discoveries that will be obtained as a result of direct observation. The purpose of this study is to provide an overview of the relationship between individual and group characteristics, structure, culture and organizational climate of the effectiveness of internal organization at the private university. This research is also expected to enrich science education administration (management level). The target to be achieved in this study can describe picture of the dynamics of the groups within the organization, the conflicts that occur and how the solution in improving organizational effectiveness.

\section{RESEARCH METHODOLOGY}

This research belonged to the category of ex post facto study which was a form of research that did not need to be in control or manipulation of variables directly by research. Embodiments of the independent variables have occurred naturally or cannot be manipulated or researchers trying to give an explanation of the facts that have occurred. Differences independent variables obtained not by manipulating the independent variables directly, but by choosing specific individuals to serve as the independent variable by using a descriptive-correlational research design. This was a descriptive type to obtain information regarding the phenomena observed today. This was a correlational study to explain whether or not the relationship between the various variables based on large-size of the correlation coefficient (Ardhana, 1987; Ary et al., 1985; Kachigan, 1982). In this research, there were several exogenous variables and some endogenous variables. Exogenous variables are those that are not influenced by other variables in the model; whereas, an endogenous variable was a variable which was influenced by other variables in the model (Asher, 1993; Cohen and Cohen, 1983).

The purpose of this study was to determine the direct and indirect relationship between individual characteristics, group characteristics, organizational structure, organizational culture and organizational climate to organizational effectiveness. This study uses a quantitative approach to the ex post facto research category and is a non-experimental research. The hypothesis of this study aims to prove the relationship between variables. Location of the study was conducted in Malang, East Java that includes a population of as 
many as 1,164 people lecturers in 55 private colleges which are spread throughout the city of Malang.

Research Instruments in this study in the form of the inquiry. The questionnaire used to collect data for the information to be obtained relating to the individual characteristics, the characteristics of the group, its organizational structure, organizational culture, organizational climate, and organizational effectiveness as perceived by the lecturers. Development of instruments includes two phases: the preparation phase ie the stage develop instruments based on the study of theory and test phase, that is to try out on the field with the goal of permanent lecturers who are not being sampled.

Relationships that exist in the path analysis is a causal relationship, ie the relationship because they exogenous affect the endogenous variables. Model relationships between variables can be shaped recursive (one way) and non-recursive (two-way or reciprocal). Path analysis is the beginning of a structural model analysis, or better known as SEM (Structural Equation Modeling). PLS method are the analysis tools to prove the hypothesis of the research undertaken. research hypothesis as follows:

1. There is a significant relationship directly between individual characteristics and the characteristics of the group / groups with an organization's effectiveness at private colleges in the city of Malang.

2. There is a significant relationship directly between individual characteristics and the characteristics of the group / group with the organizational culture in private colleges in the city of Malang.

3. There is a significant relationship directly between individual characteristics and the characteristics of the group / group with the organizational climate at private colleges in the city of Malang.

4. There is a direct significant relationship between individual characteristics and the characteristics of the group / group with the organizational structure of private colleges in the city of Malang.

5. There is a significant relationship directly between the organizational structure of the organizational culture in private colleges in the city of Malang.

6. There is a significant relationship between direct and indirect organizational culture with organizational climate at private colleges in the city of Malang.

7. There is a significant relationship between direct and indirect organizational structure, organizational culture, organizational climate and organizational effectiveness at private colleges in the city of Malang.

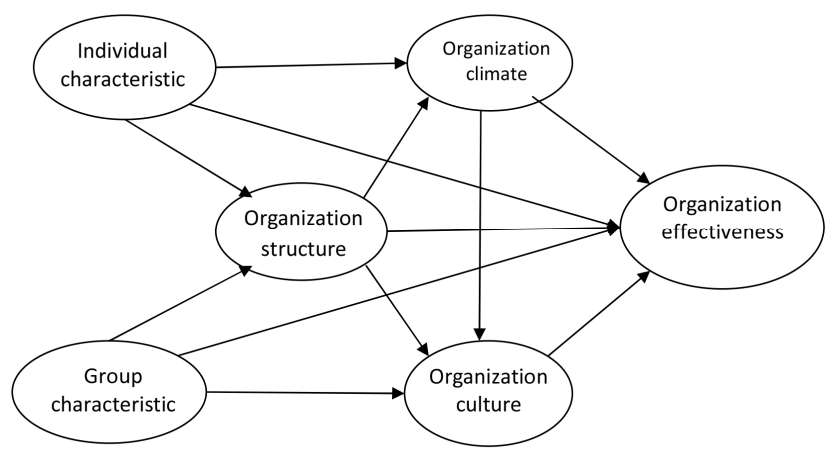

Figure 1. Research Model 


\section{Data Collection and Analysis}

The unit of analysis in this study was that individuals who were already certified permanent lecturers at private universities. As for the reason of permanent lecturers used in this study population that remained private university lecturers directly involved in the process of formation of organizational culture and climate on campus. The existence of a permanent lecturer at a private university almost every day so as to perceive the efficacy of college each, in which it is different from the part-time lecturers (outstanding faculty). The determination of the number of samples using tables compiled by Krejcie and Morgan in (Sekaran, 2003). According to (Sugiyono, 2003) tables were developed by Isaac and Michael.

Based on the table if the total population of about 1000 - 1200, the total sample of about $258-270$ or about $25 \%$ to $30 \%$ of the total population. Researchers took $30 \%$ of the total random population, which is 349.2 or rounded up to 349 people.

Table 1. Samples Distribution

\begin{tabular}{|c|l|c|c|c|}
\hline No & College Level & $\begin{array}{c}\text { Tenured } \\
\text { faculty } \\
\text { foundation }\end{array}$ & $\begin{array}{c}\text { Lecturer Civil } \\
\text { Servants }\end{array}$ & $\begin{array}{c}\text { Lecturers } \\
\text { Sample }\end{array}$ \\
\hline 1. & University & 173 & 80 & 253 \\
\hline 2. & Institute & 27 & 15 & 42 \\
\hline 3. & College & 28 & 11 & 39 \\
\hline 4. & Polytechnic & 6 & 3 & 9 \\
\hline 5. & Academy & 4 & 2 & 6 \\
\hline & Total & 238 & 111 & 349 \\
\hline
\end{tabular}

Data tenured faculty lecturer foundations and data lecturer civil servants researchers obtained through analysis studies certification file and faculty workload that was on the personnel and staffing Kopertis Area VII East Java in Surabaya for 3 months intensive. Questionnaire research as a tool to explore the data in this study disseminated by sending by registered mail to the address or email respondents by first ensuring that the email address of the respondent and is valid. To do this the researchers conducted observations to campuses where potential respondents were randomly selected and assisted by officers and a letter of introduction from the Coordinator Kopertis Region VII East Java or authorized personnel.

Analysis of the data used in this research was the analysis of structural models, or more commonly known as SEM (Structural Equation Modeling), the PLS analysis tools to build and validate the structure of the conceptual framework. Structural equation modeling (Structural Equation Modeling) was a second generation multivariate analysis technique that allows researchers to examine the relationship between complex variables both recursive and non-recursive to obtain an overall picture of the overall models.

SEM analysis techniques with PLS analysis tool used to test the hypothesis. PLS has been assuming SEM which has been able to consider issues that could not been done by other programs. PLS could provide information that was more innovative in the presentation of statistical results. So the modification of models and causes no or poor fit a model can be easily known, through the use of a moderating variable and non-linearity could be finished finished (Ghozali, 2011). 


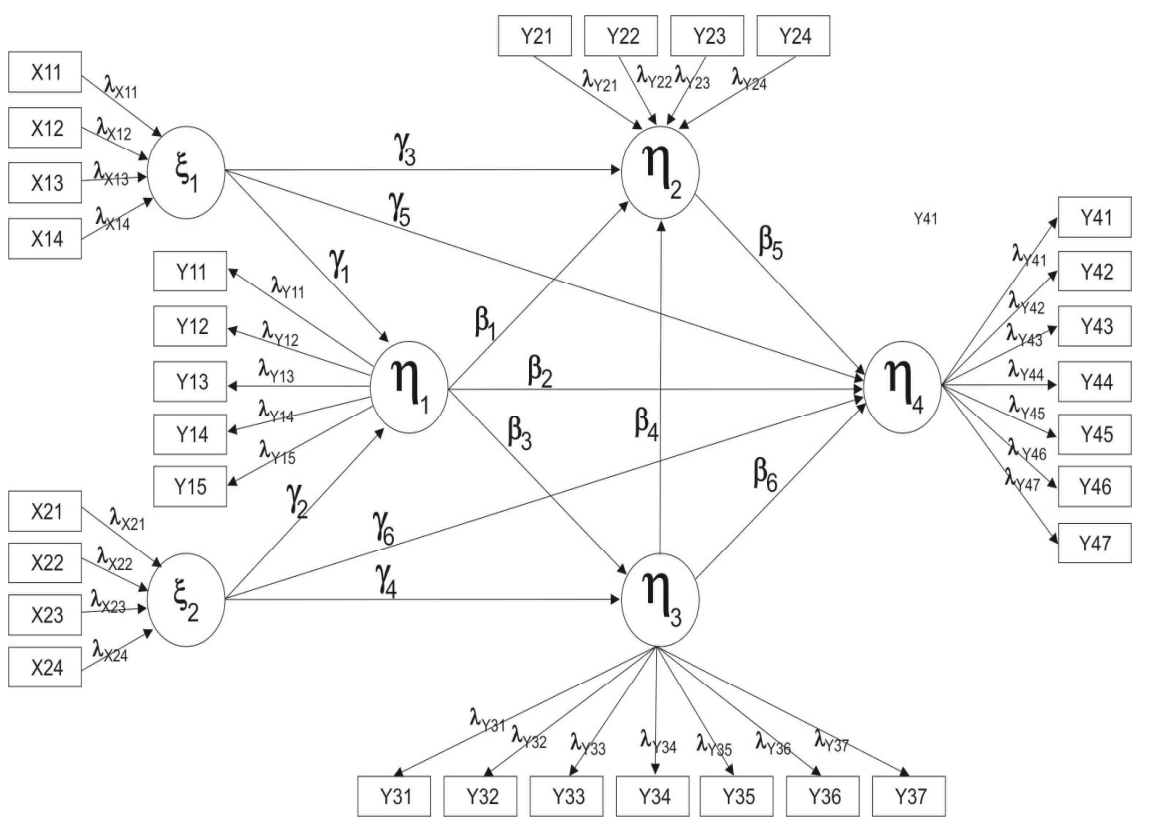

\section{RESULTS}

Figure 2. Line Diagram Interpersonal Research Variables

\section{Descriptive Research Variables}

Descriptive analysis of the study variables aimed at providing an overview of the responses or answers to the questionnaire that was given to the respondents as a tool to dig and collect data. The variables in this study, including individual characteristics, group characteristics, structure, culture, climate and organizational effectiveness of existing private universities in Malang, East Java. The parameters of the descriptive analysis of the variables used include the minimum score, score the maximum, average and standard deviation of variables and indicators in this study. Based on the results of descriptive analysis with SPSS software known that the average response of survey respondents showed a good attitude and supported this research.

\section{Inferential Analysis}

Inferential analysis was aimed at proving and testing the hypothesis of a study with previous theories and provided conclusions on the state of the population through the use of samples as a measurement parameter. Constructs in this study consisted of two kinds, among others contructs with reflective indicators, namely the organizational structure, organizational climate and organizational effectiveness. While contructs with formative indicators included individual characteristics, group characteristics and culture of the organization. For that reason the researchers chose PLS method as an approach in analyzing the structure and models in the SEM. The results of the analysis of the relationship between constructs in this study can be seen in the following figure. 


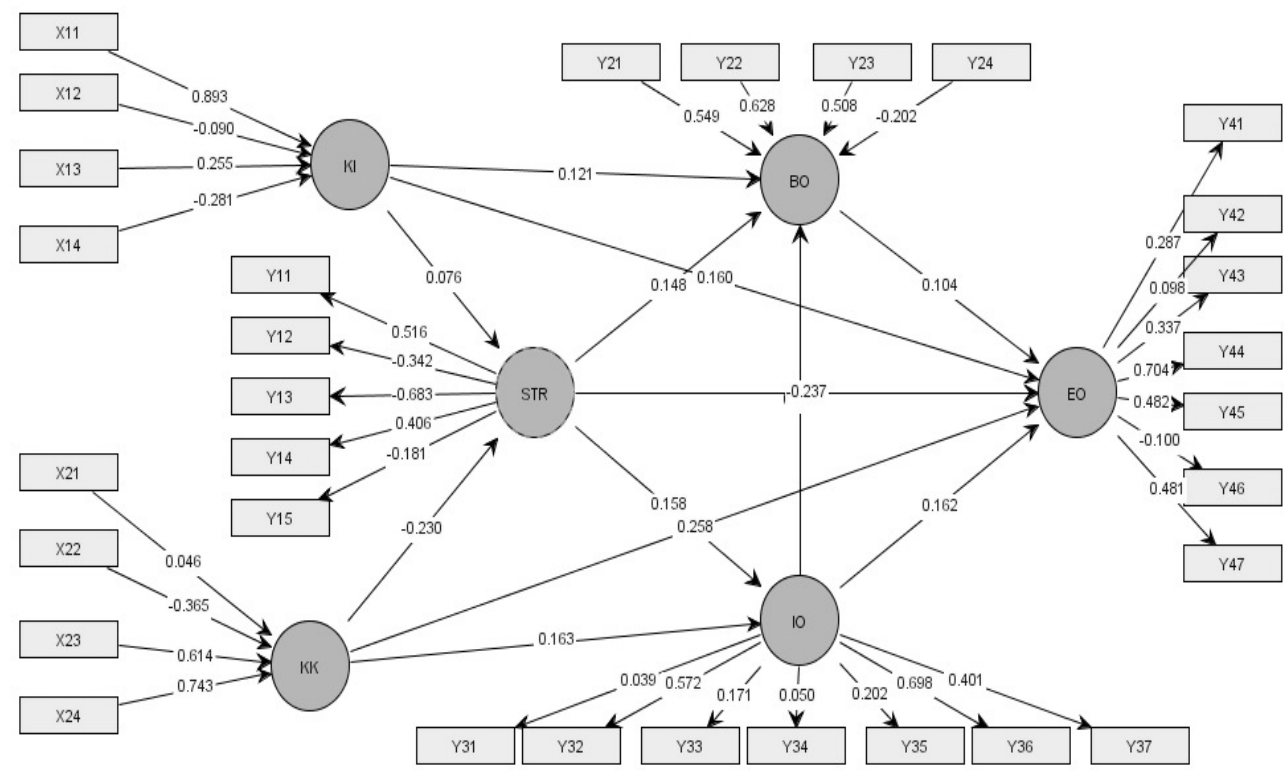

Figure 3. Result Analysis of Interpersonal Constructs Research

Based on the picture above shows that construct the structure, culture and organizational climate as moderating variable that can strengthen or weaken the relationship between individual characteristics, group characteristics and effectiveness of the organization.

Researchers found there are five (5) significant direct engagement occurs between the characteristics of the group with the organizational structure, organization climate to the culture of the organization, group characteristics with the effectiveness of the organization, the organizational structure of the effectiveness of the organization and the organizational climate of the effectiveness of the organization of which indicated that the value of T-counted more of the T-table of 0.674 with significant level of 5\%.

The coefficient value for each parameter constructs also clearly showed a significant direct relationship between the characteristics of the group with the organizational structure, organizational climate to organizational culture, characteristics of the group with an organization's effectiveness, the organizational structure of the effectiveness of the organization and organizational climate to organizational effectiveness. Relationship characteristics of the group with the organizational structure has a coefficient of -0.230 parameters of this case shows that the characteristics of the group with the organizational structure have a significant direct relationship of opposites. A significant direct relationship between organizational climate to organizational culture, which had a coefficient parameter value of 0.218 .

Coefficient parameter value between the characteristics of the groups with an organization's effectiveness 0.258 showed a significant direct relationship between them. The next significant direct relationship between the structure of the organization with the effectiveness of the organization of which both have coeffisient parameter of -0.237 , but direct contact is conflicting. Organizational climate with an organization's effectiveness also showed a significant direct relationship between the two in which the value of 
coefficient parameters between the two amounted to 0.162. Relations between the constructs in this study can be seen on the inner table following model.

Table 2. Parth Coefficients (Mean, STDEV, T-Values)

\begin{tabular}{|c|c|c|c|c|}
\hline & $\begin{array}{c}\text { original sample } \\
\text { estimate }\end{array}$ & $\begin{array}{c}\text { mean of } \\
\text { subsamples }\end{array}$ & $\begin{array}{c}\text { Standard } \\
\text { deviation }\end{array}$ & $\begin{array}{c}\text { T- } \\
\text { Statistic }\end{array}$ \\
\hline KI -> STR & 0.076 & -0.144 & 0.253 & 0.301 \\
\hline $\begin{array}{c}\text { KK -> } \\
\text { STR }\end{array}$ & -0.230 & 0.109 & 0.305 & 0.757 \\
\hline KI -> BO & 0.121 & 0.083 & 0.286 & 0.423 \\
\hline $\begin{array}{c}\text { STR -> } \\
\text { BO }\end{array}$ & 0.148 & -0.027 & 0.272 & 0.544 \\
\hline IO -> BO & 0.218 & 0.184 & 0.265 & 0.820 \\
\hline KK -> IO & 0.163 & 0.085 & 0.323 & 0.505 \\
\hline $\begin{array}{c}\text { STR -> } \\
\text { IO }\end{array}$ & 0.158 & 0.032 & 0.341 & 0.463 \\
\hline KI -> EO & 0.160 & 0.063 & 0.256 & 0.624 \\
\hline KK -> EO & 0.258 & 0.159 & 0.237 & 1.088 \\
\hline $\begin{array}{c}\text { STR -> } \\
\text { EO }\end{array}$ & -0.237 & -0.007 & 0.286 & 0.827 \\
\hline BO -> EO & 0.104 & 0.095 & 0.222 & 0.470 \\
\hline IO -> EO & 0.162 & 0.159 & 0.224 & 0.721 \\
\hline
\end{tabular}

Besides seeing the value of coefficient parameters obtained from the calculation of the inner weights above through table 4.8, other ratings in the analysis of the position or the position of the structure, culture and organizational climate seen also on the value of the correlation between each latent variable in this study. Relations between research constructs correlation can be seen from the table below of the latent variables.

Table 3. Correlation Between Latent Variables

\begin{tabular}{|c|c|c|c|c|c|c|}
\hline & KI & KK & STR & BO & IO & EO \\
\hline KI & 1.000 & & & & & \\
\hline KK & -0.055 & 1.000 & & & & \\
\hline STR & 0.089 & -0.235 & 1.000 & & & \\
\hline BO & 0.164 & -0.058 & 0.185 & 1.000 & & \\
\hline IO & 0.137 & -0.126 & 0.120 & 0.252 & 1.000 & \\
\hline EO & 0,164 & 0.319 & -0.245 & 0.112 & 0.214 & 1.000 \\
\hline
\end{tabular}

correlations between variables indicate that the characteristics of the group to contribute negatively to the individual characteristics of $5.5 \%$. The individual characteristics accounted for $8.9 \%$ and negative characteristics of the group contributed $23.5 \%$ to the organization structure. Characteristics of individuals accounted for $16.4 \%$, the 
characteristics of the group contributed negatively by $5.8 \%$ and the organizational structure contributed $18.5 \%$ to the culture of the organization.

The contribution of the individual characteristics of $13.7 \%$, group-specific characteristics contributed negatively by $12.6 \%$, amounting to $12 \%$ struktuk organization of organizational climate, yet organizational climate contributed $25.2 \%$ to the culture of the organization. Characteristics of individuals accounted for $16.4 \%, 31.9 \%$ of group characteristics, organizational structure contribute to a negative $24.5 \%$, contributing $11.2 \%$ of organizational culture and organizational climate accounted for $21.4 \%$ of the effectiveness of the organization. In the analysis with PLS method correlation results obtained through techniques bootstapping for each constructs and indicators of latent variables in this study. R-square value in PLS method used to measure the model constructs between latent variables and measure the model constructs also between latent variables with the indicator. Image measurement analysis model can be as follows.

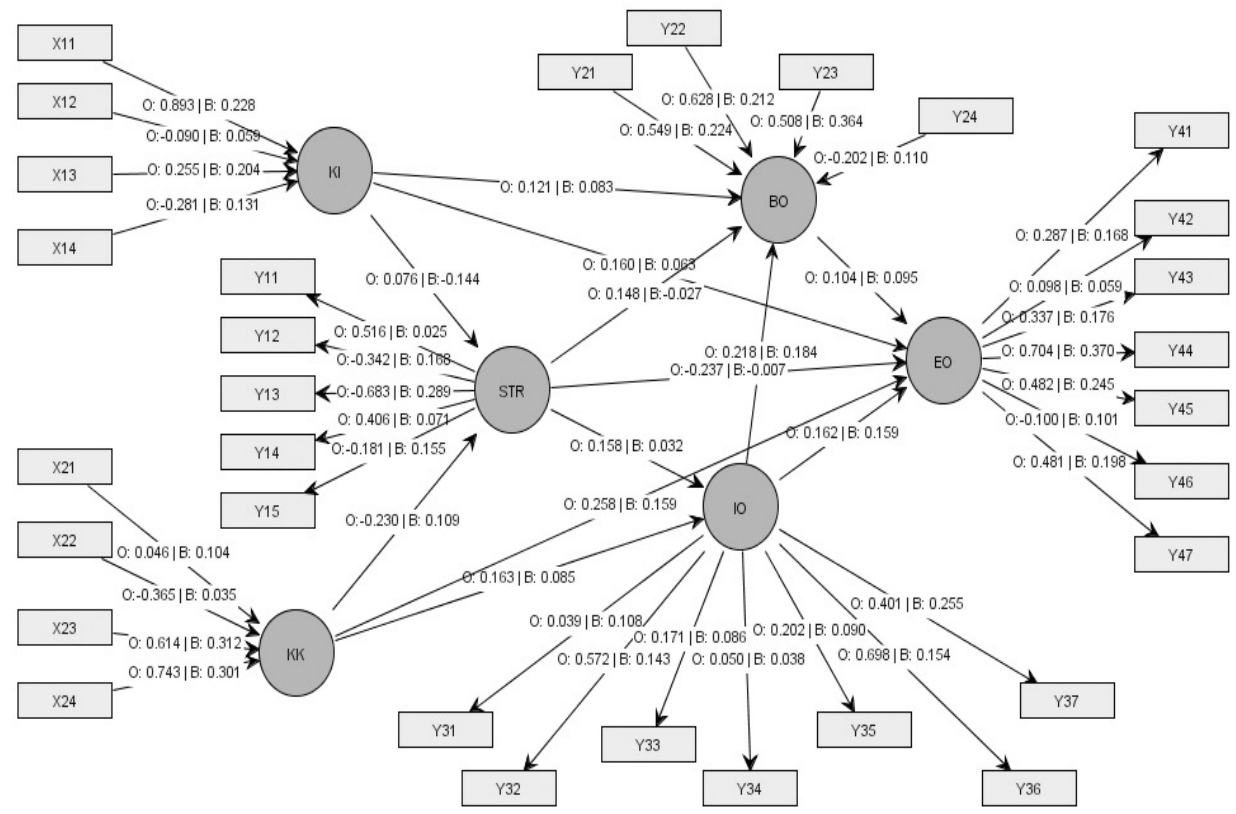

Figure 4. Model Inter Construct Research

The result of the path coefficients in the initial model, statistically there are 7 (seven) relationships that are not proven to have a significant influence (T-count $<$ T-table) is a direct relationship between individual characteristics to the organizational structure, the individual characteristics of the organizational culture, organizational structure with organizational culture, a direct relationship between the characteristics of the group with the organizational climate, a direct relationship between the organizational structure with organizational climate, a direct relationship between individual characteristics with the effectiveness of the organization, as well as a direct link between organizational culture with organizational effectiveness. 
Journal of Social Sciences (COES\&RJ-JSS), 5(4), pp. 506-522

Table 4. Hypothesis Testing Results Summary

\begin{tabular}{|c|c|c|}
\hline Hypothesis & Hypothesis statements & $\begin{array}{l}\text { Results of hypothesis } \\
\text { testing }\end{array}$ \\
\hline $\mathrm{H} 1$ & $\begin{array}{l}\text { There was a significant relationship directly } \\
\text { between individual characteristics and the } \\
\text { characteristics of the group with an organization's } \\
\text { effectiveness at private universities in Malang }\end{array}$ & Accepted \\
\hline $\mathrm{H} 2$ & $\begin{array}{l}\text { There was a significant relationship directly } \\
\text { between the individual characteristics of the } \\
\text { organizational culture at private universities in } \\
\text { Malang }\end{array}$ & Rejected \\
\hline $\mathrm{H} 3$ & $\begin{array}{l}\text { There was a significant relationship directly } \\
\text { between the characteristics of the group with the } \\
\text { organizational climate at universities in Malang }\end{array}$ & Rejected \\
\hline $\mathrm{H} 4$ & $\begin{array}{l}\text { There was a significant relationship directly } \\
\text { between individual characteristics and the } \\
\text { characteristics of the groups with struktuk } \\
\text { organization at private universities in Malang }\end{array}$ & Accepted \\
\hline H5 & $\begin{array}{l}\text { There was a significant relationship directly } \\
\text { between the organizational structure with } \\
\text { organizational culture and climate at private } \\
\text { universities in Malang }\end{array}$ & Rejected \\
\hline $\mathrm{H} 6$ & $\begin{array}{l}\text { There was a significant relationship directly } \\
\text { organizational climate to organizational culture at } \\
\text { private universities in Malang }\end{array}$ & Accepted \\
\hline $\mathrm{H} 7$ & $\begin{array}{l}\text { There is a significant relationship between direct } \\
\text { and indirect structure, culture, organizational } \\
\text { climate and organizational effectiveness at private } \\
\text { universities in Malang }\end{array}$ & Accepted \\
\hline
\end{tabular}

Based on the hypothesis test result above that of 7 there are three hypotheses research hypothesis is rejected and four accepted hypothesis at a significance level of 5\%. Furthermore, the research findings can be structured summaries hypothesis testing as presented in the following table.

The results of modeling with PLS analysis with a view to illustrate the relationship six variables studied, there are three paths is not significant and there is a four-lane proved significantly. Four significant proven track is a direct relationship between the characteristics of the groups with the effectiveness of the organization, individual characteristics and the characteristics of the group with the organizational structure, organizational climate to organizational culture and structure, climate and culture of the organization with an organization's effectiveness. End models found in this study are described in the following figure. 


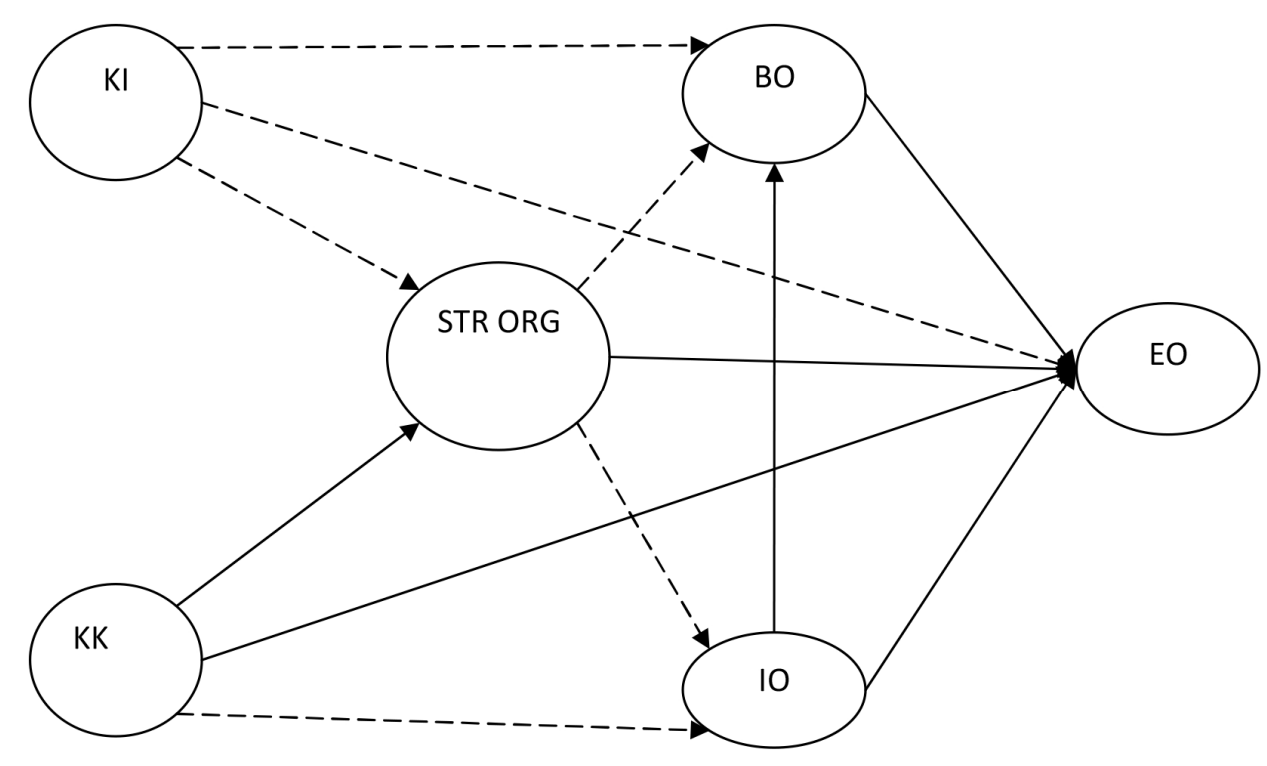

Figure 5. The final model

Information: no significant direct relationship significant relationships directly

In the final model explained that that the variable characteristics of the group are directly related to the effectiveness of the organization, group characteristics also play a direct role in the existence of the organizational structure. Organizational climate becomes a strategic factor to organizational culture and have a direct relationship. An organization's effectiveness is determined by the structure, climate and culture that flourished in the organization.

\section{DISCUSSIONS}

Some things that are important in their group characteristics are common destiny and power because of the position that affects the dynamics and the existence of groups within an organization. That the private college where the composition of the group of lecturers and professors remained fixed foundations lecturer civil servants bit much effect on the effectiveness of the college. Through certification can minimize the occurrence of lecturers perceived groups unproductive professors and minimizes conflicts between groups in private colleges. Expected future all lecturers in Indonesia have rights and obligations as well as the same income among tenured faculty with tenured faculty foundation of civil servants, the difference between them is the performance of each faculty.

The group managed to occupy an important position in the organization will put the interests of their group in each of the various decision-making organizations. The majority would dominate any decisions and activities undertaken in the organization. This is consistent with the dynamics in college one of which is a power struggle and the political process in college. 
The organizational structure directly affect the effectiveness of the organization in the structure where there is a division of tasks and roles are divided through the hierarchy and authority. The organizational structure of private colleges formalistic affect acceleration and effectiveness of decision-making that requires spontaneous mechanism. Once again the ability of a leader is very important in running and sustainability of the existence of private universities. Leadership both at the rector or program of study must have qualified managerial skills so that the entire academic community can learn and work comfortably.

Cultural organization was formed by the founder of the organization, so that if the private college organizational culture is transmitted and built by the founders of the college. Each college has a different culture that is reflected in the logo, vision, mission, goals and objectives to be achieved. Quite often also reflected in the form of buildings, the color of the building, as well as the uniform of the lecturers and employees. An organizational culture that is very easy to see at the time of graduation and anniversary kegian activities conducted by the university.

Organizational effectiveness can only be achieved if the climate that exists in the organization is open. Where is the openness of each member of the organization can work and carry out their duties with a sense of security and comfort. Confidence in the leadership will encourage employees to voluntarily devote himself to his work and the institution to which he belongs.

Private colleges have an open organizational climate can provide a conducive academic atmosphere for the creation of the implementation of learning for students. Conducive academic atmosphere that will encourage students, faculty and employees to come forward and aspirations, be innovative and creative that enhance the development of science and technology. Creative thinking and innovative indispensable in achieving the targets and goals of private universities as the basic capital in recruiting new students. Private universities are highly dependent on the number of students to achieve the goals and targets set jointly by the founders.

\section{CONCLUSION}

Based on the findings and implications of this research, made a conclusion; (1) The effectiveness of private universities is influenced by several factors, both directly and indirectly, a factor directly related to the effectiveness of the organization included group characteristics, organizational structure, culture and organizational climate; (2) The role of individual characteristics were not directly related to the effectiveness of the organization at a private university in the city of Malang; (3) Characteristics of the group were directly related to the effectiveness of the organization at a private university in Malang; (4) Individual characteristics were not directly related to the organizational culture in private colleges in the city of Malang; (5) Characteristics of groups not directly related to the organizational culture in private colleges in the city of Malang; (6) The individual characteristics were not directly related to the organizational climate at private universities in Malang; (7) Characteristics of the group was not directly related to the organizational climate at the university in the city of Malang; (8) Through the organizational structure, the characteristics of the group also had a significant relationship with an organization's effectiveness at universities in Malang; (9) The characteristics of groups were not directly related to the organizational climatetowards the private 
university in the city of Malang; 10) The organizational structure did not deal directly with the organization's culture and climate of private colleges in the city of Malang; (11) Organizational climate was directly related to the organizational culture of universities in Malang.

It has been suggested that: (1) The description of the effectiveness of the internal organization of private universities in the characteristics of individuals, the power of motivation, communication systems, the interaction process of mutual influence, decisionmaking process, the formulation of goals and giving orders, and process control should be used as an input the leaders of private universities in Malang, where in determining strategy in establishing and implementing the organizational structure, strengthen the culture of the organization, and creating a conductive climate of organizational for private colleges that led to the creation of private universities are effective and efficient; (2) To evaluate the effectiveness of private universities as a reference or basis for fostering and developing the private universities as well as the basis for making policies with regard to the process of higher education at private colleges; (3) In order to improve the quality of graduates of private colleges, assessment and evaluation of the effectiveness of the college can be used ingredient in making the development of policies relating to the implementation of higher education and its dynamics in the private colleges; (4) Based on observations and interviews with faculty researchers and lecturers still remains the foundation of civil servants in terms of internal factors determining the effectiveness of the college was still variations. There are some colleges that already factors that can be used for analysis in determining an organization's effectiveness. In relation to this, the need for commonality and standardization of the nature and universally applicable in evaluating and assessing the effectiveness of private universities so that there are no gaps are very much amongst private universities.

\section{REFERENCES}

Abouzeedan, A., \& Hedner, T. (2012). Organization structure theories and open innovation paradigm. World Journal of Science, Technology and Sustainable Development, 9(1), 6-27. http://doi.org/10.1108/20425941211223598

Ali Mohammad Mosadegh Rad. (2006). The impact of organizational culture on the successful implementation of total quality management. The TQM Magazine, 18(6), 606625. http://doi.org/10.1108/09544780610707101

Alma, B. (2004). Manajemen Pemasaran Dan Pemasaran Jasa. Bandung: Alfabeta. APTISI. (2012). Direktori Perguruan Tinggi Swasta Indonesia. Jakarta: APTISI.

Ardhana, W. (1987). Bacaan Pilihan dalam Metode Penelitian Pendidikan. Jakarta: Proyek Pengembangan Lembaga Pendidikan Tenaga Kependidikan DIKTI.

Arikunto, S. (2006). Prosedur Penelitian: Suatu Pendekatan Praktik. Jakarta: Rineka Cipta.

Armia, C. (2002). Pengaruh Budaya terhadap Efektivitas Organisasi: Dimensi Budaya Hofstede. Jurnal Akuntansi \& Auditing Indonesia, 6(1). Retrieved from http://www.jurnal.uii.ac.id/index.php/JAAI/article/view/870

Ary, D., Jacobs, L. C., \& Razavieh, A. (1985). Introduction to Research in Education. 3th Edition (3th ed.). New York: CBS College Publising.

Asher, H. B. (1983). Causal Modelling 2nd Edition. SAGE Publication. Bangun, W. (2011). Intisari Manajemen. Bandung: Refika Aditama.

BAN-PT. (2011). Borang Akreditasi. Jakarta: Badan Akreditasi Nasional Perguruan Tinggi. 
Birkinshaw, J., Nobel, R., \& Ridderstråle, J. (2002). Knowledge as a Contingency Variable: Do the Characteristics of Knowledge Predict Organization Structure? Organization Science, 13(3), 274-289. http://doi.org/10.1287/orsc.13.3.274.2778 Borg, W. R., \& Gall, M. D. (1983). Educational Research An Introduction 4th Edition (4th ed.). New York: Longman.

Brahmasari, I. A., \& Suprayetno, A. (2009). Pengaruh Motivasi Kerja, Kepemimpinan dan Budaya Organisasi Terhadap Kepuasan Kerja Karyawan serta Dampaknya pada Kinerja Perusahaan (Studi kasus pada PT. Pei Hai International Wiratama Indonesia). Jurnal Manajemen Dan Kewirausahaan (Journal of Management and Entrepreneurship), 10(2), 124-135. http://doi.org/10.9744/jmk.10.2.pp. 124-135

Burke, W. W., \& Litwin, G. H. (1992). A Causal Model of Organizational Performance and Change. Journal of Management, 18(3), 523-545.

http://doi.org/10.1177/014920639201800306

Cameron, K. S. (1986). Effectiveness as Paradox: Consensus and Conflict in Conceptions of Organizational Effectiveness. Management Science, 32(5), 539-553.

http://doi.org/10.1287/mnsc.32.5.539

Campion, M. A., Papper, E. M., \& Medsker, G. J. (1996). Relations Between Work Team Characteristics and Effectiveness: A Replication and Extension. Personnel Psychology, 49(2), 429-452. http://doi.org/10.1111/j.1744-6570.1996.tb01806.x

Cheng, Y. C. (1993). Profiles of Organizational Culture and Effective Schools. School Effectiveness and School Improvement, 4(2), 85-110.

http://doi.org/10.1080/0924345930040201

Cohen, J., \& Cohen, P. (1983). Applied Multiple Regression Correlation Analysis for Behavioral Science 2nd Edition. Engelwood Cliffs: Lawrence Erlbaum Assosiate Publisher.

Creemers, B. P. M., \& Reynolds, D. (1991). School Effectiveness and School Improvement, An International Journal of Research Policy and Practice. New Jersey: Swets \& Zeitlinger.

Daft, R. L. (2007). Organization theory and design (9th ed). Mason, OH: Thomson SouthWestern.

Danim, S. (2012). Motivasi, Kepemimpinan, Dan Efektivitas Kelompok. Jakarta: Rineka Cipta.

Darmasetiawan, N. K. (2001). Pengaruh Iklim Organisasi dan Komitmen Organisasional dan Dampaknya terhadap Upaya Dosen dalam meningkatkan Jabatan Akademis (Studi pada Dosen Tetap Ubaya). Malang: Pascasarjana Universitas Brawijaya Malang.

DeRoche, E. F. (1987). An Administrator's Guide for Evaluating Programs and Personel: An Effective School Approach. Boston: Allyn and Bacon.

Devine, D. J., Clayton, L. D., Philips, J. L., Dunford, B. B., \& Melner, S. B. (1999). Teams in Organizations Prevalence, Characteristics, and Effectiveness. Small Group Research, 30(6), 678-711. http://doi.org/10.1177/104649649903000602

Ferdinand, A. (2000). Struktural Equation Modelling Dalam Penelitian Manajemen. Semarang: Universitas Diponegoro Press.

Field, R. H. G., \& Abelson, M. A. (1982). Climate: A Reconceptualization and Proposed Model. Human Relations, 35(3), 181-201. http://doi.org/10.1177/001872678203500302 Garmendia, J. A. (2004). The Impact of Corporate Culture on Company Performance. Current Sociology, 52(6), 1021-1038. http://doi.org/10.1177/0011392104046620 Ghozali, I. (2011). Struktural Equation Modeling Metode Alternatif Dengan Partial Least Square (PLS). Semarang: Badan Penerbit Universitas Diponegoro. 
Gibson, J. ., Ivancevich, J. ., \& Donelly, J. . (1988). Organizations: Behavior, Structure and Process. Plano: Business Publication.

Gordon, J. . (1991). A Diagnostic Approach to Organizations Behavioe. Plano: Business Publication.

Greenberg, J., \& Baron, R. . (1995). Behavior In Organizations, Understanding and Managing The Human Side of Work. Engelwood Cliffs: Prentice Hall.

Hall, R. ., \& Tolbert, P. . (2005). Organizations: Structure, Processes, and Outcomes. 9th Edition. New Jersey: Pearson Prentice Hall.

Hasibuan, M. S. . (2005). Organisasi dan Motivasi. Dasar Peningkatan Produktifitas. Jakarta: Bumi Aksara.

Henri, J.-F. (2006). Organizational culture and performance measurement systems. Accounting, Organizations and Society, 31(1), 77-103.

http://doi.org/10.1016/j.aos.2004.10.003

Hoy, K. W., \& Miskel, C. G. (2001). Educational Administration: Theory, Research and Practice. New York: McGraw Hill Inc.

Hoy, W. K., \& Miskel, C. G. (2013). Educational Administration, Theory, Research and Practice 9th Edition. New Jersey: McGraw Hill Inc.

Hoy, W. K., Tarter, C. J., \& Bliss, J. R. (1990). Organizational Climate, School Health, and Effectiveness: A Comparative Analysis. Educational Administration Quarterly, 26(3), 260-279. http://doi.org/10.1177/0013161X90026003004

Ivancevich, J. ., Konopaske, R., \& Matterson, M. . (2005). Organizational Behavior and Management 7th Edition. New Jersey: Prentice Hall.

John, I. M., Konopaske, R., \& Matteson, T. M. (2007). Organizational Behavior and Management. Seventh Editions. Terjemahan Jilid.

Johnson, B., \& Christensen, L. (2004). Educational Research: Quantitative, Qualitative, and Mixed Approaches. Boston: Pearson Allyn and Bacon.

Kreitner, R., \& Kinicki, A. (1992). Organizational Behavior (2nd ed.). Boston: IRWIN Homewood.

Marie Mikic Little, \& Alison M. Dean. (2006). Links between service climate, employee commitment and employees' service quality capability. Managing Service Quality: An International Journal, 16(5), 460-476. http://doi.org/10.1108/09604520610686133

Mary Bambacas, \& Margaret Patrickson. (2008). Interpersonal communication skills that enhance organisational commitment. Journal of Communication Management, 12(1), 5172. http://doi.org/10.1108/13632540810854235

Miner, J. B. (1988). Organizational Behavior, Performance and Productivity. New York: Random House Inc.

Nasution, B. (2006). Memilih Jalan Pendidikan Kita. Utan Kayu: Research Institute for Islamic Curiculum. Jakarta: Ghalia Indonesia.

Organ, D. W. (1994). A Special Issue of The Journal of ManagementPersonality and organizational citizenship behavior. Journal of Management, 20(2), 465-478.

http://doi.org/10.1016/0149-2063(94)90023-X

Ostroff, C., Kinicki, A. J., \& Tamkins, M. M. (2003). Organizational Culture and Climate. John Wiley \& Sons, Inc.

Pink, D. H. (2011). Drive: The surprising truth about what motivates us. New York:

Penguin. Retrieved from http://books.google.com/books?hl=en\&lr=\&id=A-

agLi2ldB4C\&oi=fnd\&pg=PP1\&dq=\%22fully+account + for + who+we+are + We+also + had $+\mathrm{a}+$ second+drive $\% \mathrm{E} 2 \% 80 \% 94$ to+seek+reward+and+avoid+punishment $\% 22+\% 22$ clerk $+\mathrm{i}$ $\mathrm{s}+$ mostly+algorithmic. + You+do+pretty+much+the+same+thing+over+and+over+in+a+ce rtain+way.+Creating\%22+\&ots=LgH9Uk4C2i\&sig=1QpQTIAk6btKMmcj-vnlge-MKUA 
Prihatiningsih, T. S. (2004). Quality Assurance in Higher Education An International Movement. Yogyakarta: Presented at the national Meeting of Chief Quality Officers at Gadjah Mada University.

Qudratullah, M. . (2013). Analisis Regresi Terapan Teori, Contoh Kasus, Dan Aplikasi Dengan SPSS. Yogyakarta: CV Andi Offset.

Ramayanawati, S. (2007). Strategi Perguruan Tinggi Swasta Komputer Dalam

Meningkatkan Daya Saing (Studi Multi-Kasus pada STMIK Pradya Paramitha dan STIKI Malang) (Tesis Tidak Diterbitkan). Malang: Universitas Negeri Malang.

Robbin, S. P. (2003). Organizational Behavior 10th Edition (tenth). Upper Saddle River, New Jersey: Pearson Education Inc.

Robbins, S. . (2001). Teori Organisasi: Struktur, Desain dan Aplikasi. Terjemahan oleh: Arcan. Jakarta: Penerbit Erlangga.

Sadri, G., \& Lees, B. (2001). Developing corporate culture as a competitive advantage.

Journal of Management Development, 20(10), 853-859.

Sarwono, J. (2012). IBM SPSS Advanced Statistic: Prosedur-Prosedur Generalisasi dan Perluasan General Linear Model (GLM). Yogyakarta: Penerbit Andi.

Sarwono, S. W. (1999). Psikologi Sosial Kelompok dan Terapan. PT Balai Pustaka.

Sekaran, U. (2003). Research Methods for Business 4th Edition. New York: John Wiley \& Sons, Inc.

Sergiovanni, T. J., Burlingame, M., Coombs, F. S., \& Thurston, P. W. (1987). Educational Governance and Administration. Engelwood Cliffs: Prentice Hall.

Silalahi, U. (2011). Asas Asas Manajemen. Bandung: PT Refika Aditama.

Singarimbun, M., \& Efendy, S. (1995). Metode Penelitian Survey Edisi Revisi. Jakarta:

Bumi Aksara.

Soetopo, H. (2010). Perilaku Organisasi Teori dan Praktik Di Bidang Pendidikan.

Bandung: PT Remaja Rosdakarya.

Somantri, A., \& Muhidin, S. A. (2006). Aplikasi Statistika Dalam Penelitian. Bandung: CV Pustaka Setia.

Sonhadji, A., \& Huda A.Y, M. (2014). Asesmen Kebutuhan, Pengambilan Keputusan, Dan Perencanaan Matarantai dalam Manajemen Pendidikan (Kesatu). Malang: UM Press.

Sonhadji, A. K. . (1991). Birokrasi, Hubungan Manusia, Dan Budaya Dalam Organisasi. Malang: PPS IKIP Malang.

Steers, R. . (1985). Efektivitas Organisasi, Kaidah Perilaku. Terjemahan Magdalena Yamin. Jakarta: Erlangga.

Steers, R. ., \& Porter, L. . (1983). Motivational and Work Behavior. New York: McGraw Hill Inc.

Subkhi, A., \& Jauhar, M. (2013). Pengantar Teori Dan Perilaku Organisasi (Kesatu). Jakarta: Prestasi Pustakaraya.

Subyantoro, A. (2009). Karakteristik Individu, Karakteristik Pekerjaan, Karakteristik Organisasi dan Kepuasan Kerja Pengurus yang Dimediasi oleh Motivasi Kerja (Studi pada Pengurus KUD di Kabupaten Sleman). Jurnal Manajemen Dan Kewirausahaan (Journal of Management and Entrepreneurship), 11(1), 11-19. http://doi.org/10.9744/jmk.11.1.pp. 11-19

Sudarmanto, R. . (2005). Analisis Regresi Linier Ganda dengan SPSS. Yogyakarta: Graha Ilmu.

Sugiyono. (2003). Metode Penelitian Bisnis. Bandung: CV. Alfabeta.

Sukrisno, H. (2008). Hubungan Antara Responsibilitas Manajemen, Akuntabilitas Mutu Pelayanan, Budaya Mutu, Pembelajaran Organisasi, Kinerja Tim Dengan Keefektifan 
Sistem Penjaminan Mutu Pada Universitas Swasta Di Surabaya (Disertasi Tidak Diterbitkan). Malang: Universitas Negeri Malang.

Sutrisno, E. (2009). Manajemen Sumber Daya Manusia. Jakarta: Penerbit Kencana. Taguiri, R., \& Litwin, G. . (1968). Organizational Climate. Boston: Harvard Business School.

Tepeci, M., \& Bartlett, A. L. B. (2002). The hospitality industry culture profile: a measure of individual values, organizational culture, and person-organization fit as predictors of job satisfaction and behavioral intentions. International Journal of Hospitality Management, 21(2), 151-170. http://doi.org/10.1016/S0278-4319(01)00035-4 Thomas, J. C. (2008). Administrative, Faculty, and Staff Perceptions of Organizational Climate and Commitment in Christian Higher Education. Christian Higher Education, 7(3), 226-252. http://doi.org/10.1080/15363750701818428

Thoyib, A. (2005). HUBUNGAN KEPEMIMPINAN, BUDAYA, STRATEGI, DAN KINERJA: PENDEKATAN KONSEP. Jurnal Manajemen Dan Kewirausahaan (Journal of Management and Entrepreneurship), 7(1), 60-73. http://doi.org/10.9744/jmk.7.1.pp. 60-73

Tika, P. (2010). Budaya Organisasi dan Peningkatan Kinerja. Jakarta: Bumi Aksara. Retrieved from http://repository.unikom.ac.id/repo/sector/buku/view/1/key/11889/Budaya-Organisasidan-Peningkatan-Kinerja-Perusahaan.html

Tilaar, H. A. . (1997). Pengembangan Sumberdaya Manusia Dalam Era Globalisasi Vis, Misi dan Program Aksi Pendidikan dan Pelatihan Menuju 2020. Jakarta: Gramedia. Wexley, K. N., \& Yukl, G. A. (2005). Perilaku Organisasi dan Psikologi Personalia. Jakarta: Rineka Cipta.

Wirawan, W. (2008). Budaya dan Iklim Organisasi Teori Aplikasi Dan Penelitian (Kedua). Jakarta: Salemba Empat.

Woods, J. A. (1997). The six values of a quality culture. National Productivity Review, 16(2), 49-55. http://doi.org/10.1002/npr.4040160207

Yamin, S., \& Kurniawan, H. (2009). Struktural Equation Modeling. Belajar Lebih Mudah Teknik Analisis Data Kuesioner Dengan Lisrel - PLS. Jakarta: Penerbit Salemba Infotek. Zheng, W., Yang, B., \& McLean, G. N. (2010). Linking organizational culture, structure, strategy, and organizational effectiveness: Mediating role of knowledge management. Journal of Business Research, 63(7), 763-771.

http://doi.org/10.1016/j.jbusres.2009.06.005

Zoe S. Dimitriades. (2007). The influence of service climate and job involvement on customer-oriented organizational citizenship behavior in Greek service organizations: a survey. Employee Relations, 29(5), 469-491. http://doi.org/10.1108/01425450710776290 